Article

\title{
Profiling Visitors to Romanian Ecotourism Destinations
}

\author{
Cristinel Petrișor Constantin 1,*®D, Vasile Papuc-Damașcan ${ }^{2} \mathbb{D}$, Andrei Blumer ${ }^{2}$, Ruxandra-Gabriela Albu ${ }^{1}$, \\ Titus Suciu ${ }^{1}$, Adina Nicoleta Candrea ${ }^{1}$ and Ana Ispas ${ }^{1}$ \\ 1 Faculty of Economic Sciences and Business Administration, Transilvania University of Brașov, \\ 500036 Brașov, Romania; ruxandra.albu@unitbv.ro (R.-G.A.); titus.suciu@unitbv.ro (T.S.); \\ adina.candrea@unitbv.ro (A.N.C.); ispasana@unitbv.ro (A.I.) \\ 2 Association of Ecotourism in Romania, 500051 Brașov, Romania; bogdan.papuc@gmail.com (V.P.-D.); \\ andrei.blumer@gmail.com (A.B.) \\ * Correspondence: cristinel.constantin@unitbv.ro; Tel.: +40-0727-39-2380
}

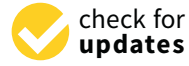

Citation: Constantin, C.P.;

Papuc-Damașcan, V.; Blumer, A.;

Albu, R.-G.; Suciu, T.; Candrea, A.N.; Ispas, A. Profiling Visitors to Romanian Ecotourism Destinations. Sustainability 2021, 13, 2958.

https://doi.org/10.3390/su13052958

Academic Editor: Nikolaos Boukas

Received: 31 January 2021

Accepted: 4 March 2021

Published: 9 March 2021

Publisher's Note: MDPI stays neutral with regard to jurisdictional claims in published maps and institutional affiliations.

Copyright: (c) 2021 by the authors. Licensee MDPI, Basel, Switzerland. This article is an open access article distributed under the terms and conditions of the Creative Commons Attribution (CC BY) license (https:/ / creativecommons.org/licenses/by/ $4.0 /)$.

\begin{abstract}
Visitors' increasing interest in nature-based and cultural tourism, especially in the context of ecotourism destinations, has generated a heated debate in tourism literature. Some authors consider that ecotourism should be approached through a niche strategy rather than through mass marketing. Therefore, identifying the main characteristics of visitors to ecotourism destinations is very important in setting management and marketing strategies adapted to their specific needs. The present paper aims to identify the profile of visitors to Romanian ecotourism destinations, considering the ecotourism potential of this country and the scarcity of empirical studies on these types of destinations. To reach this aim, a survey was conducted in four Romanian ecotourism destinations. By computing the data collected from a sample of 1157 visitors, four visitor segments have been identified based on a single characteristic (visit purpose). Crosstabulation and Chi-square analysis were used in order to identify the profiles of these segments. The results reveal that most of respondents are nature travellers, followed by culture travellers. The findings may be used by ecotourism destination managers in order to target specific market segments and establish proper management and marketing strategies.
\end{abstract}

Keywords: ecotourism destination; visitor segmentation; visitor profile; nature traveller; culture traveller; leisure traveller; eclectic traveller; sustainable development; marketing and management strategies

\section{Introduction}

Given the growing interest worldwide in ecotourism, based on natural and cultural resources, it is in these special areas that the challenges of marketing are the greatest. Ecotourism sites have moved away from mass marketing, toward target marketing: identifying market segments, selecting one or more of them, and developing tailored products and programs [1]. A challenging task for ecotourism marketers is to study the changing nature of tourism consumers [2]. Marketing activities should target identified appropriate markets only, rather than the generic mass market. Therefore, research needs to be undertaken to provide a systematic basis for policy and planning where the information content in marketing should be matched to market segments [3].

Profiling visitors to tourism destinations is particularly important for tourism marketers. Profiling is one of the phases in market segmentation [4]. Segmentation and market targeting are the best strategies for recognising potential tourist behaviours [5] in different types of tourism destinations. Understanding visitor profiles helps to identify target markets, craft meaningful messages, and develop products and resources in such a way that they meet particular demands [6]. Visitor profile and behaviour is a critical determining factor that influences the management approach for achieving multiple aspirational goals such as high visitor satisfaction and site sustainability [7].

Researchers have profiled visitors from various ecotourism areas-North America (e.g., [8]), South America (e.g., [9]), Africa (e.g., [10]), Asia (e.g., [11]), Australia (e.g., [7]), Eu- 
rope (e.g., [12])—using variables such as age, education and income [7,8,11], nationality [10], motivations [9,13], on-site activities [13], accommodation preferences [10], information sources [7], etc. However, little research $[14,15]$ has been published on the Romanian ecotourism market to understand the characteristics of visitors to ecotourism areas from in this country, particularly of domestic tourists.

Romania has a unique natural heritage that offers an excellent chance of transforming the country into a special attraction for both the international and domestic ecotourism market. It has some of the largest areas with virgin forests still remaining in Europe and the large majority of European brown bears, wolves, and globally outstanding flora and fauna [16]. In the last decade, ecotourism in Romania has evolved from isolated ecotourism programs proposed by local/national tour operators to integrated ecotourism destinations, which are developed through strategic partnerships (between local authorities, local communities, business owners) and promoted through the efforts of local or national (eco) tourism associations [17].

Nevertheless, the profile of visitors to ecotourism destinations from Romania has not been studied, as far as we know. In this respect, our study seeks to fill this gap given that identifying some segments of visitors could be helpful for planning, managing, and marketing a tourist destination. The information about the typology and profile of visitors allows ecotourism destination managers to approach their different motivations and experiences in order to understand which types of visitors are more likely to be found in different stages of tourist areas' development. Moreover, when problems arise in terms of sustainability, especially in certain types of destinations (e.g., protected areas), it is necessary to outline a typology of visitors in order to manage the access flows in the destination. The tourist facilities and other resources should also be tailored to the visitors' typology and profile. Starting from these considerations, the following objectives have been established for our research: (O1) to identify the demographic and travel characteristics of visitors to the main ecotourism destinations from Romania; $(\mathrm{O} 2)$ to define the segments of visitors to these destinations according to their visit purpose; (O3) to compare the repetitive visiting behaviour to the ecotourism destinations of the identified segments; $(\mathrm{O} 4)$ to profile these segments as regards their dominant demographic characteristics.

In order to reach the above mentioned objectives, a survey was conducted in four ecotourism destinations from Romania. The questionnaire design and data collection process were conducted by the Association of Ecotourism in Romania (AER), with the aim of offering the information support for developing and professionalising the management of ecotourism destinations in Romania. The present study only used the questions meant to accomplish the objectives regarding the identification of visitors' profile in the studied ecotourism destinations. The data collected were analysed using univariate and bivariate methods to summarize the responses, and the Chi-square test was used in order to highlight the statistical significance of the differences between the encountered visitors groups. The findings emphasize four visitors segments determined on an "a priori segmentation" approach: nature, culture, leisure, and eclectic travellers. They have different dominant and travel characteristics highlighted in the conclusion section.

\section{Literature Review}

According to a definition provided by the Global Ecotourism Network (GEN), "ecotourism is responsible travel to natural areas that conserves the environment, sustains the wellbeing of the local people, and creates knowledge and understanding through interpretation and education of all involved (visitors, staff and the visited)" [18]. In this respect, ecotourists are interested in exploring both natural attractions and cultural or historical sites [19]. They have a genuine interest in environmental responsibility in tourism and support the green tourism suppliers [20]. According to the findings highlighted in the specialty literature, ecotourists are mainly interested in relatively undisturbed ecosystems and want to learn more about natural phenomena with the aim of contributing to the sustainable development of natural sites [21]. The following activities are mentioned among 
the most popular: photography and landscape painting, studying the flora and fauna, cultural sightseeing, and special guided hikes [22]. Such activities and motivations could be considered as segmentation criteria in ecotourism [23].

The abovementioned characteristics of ecotourism are mainly related to the protected areas, which are considered "clearly defined geographical spaces, recognised, dedicated and managed through legal or other effective means, to achieve the long-term conservation of nature with associated ecosystem services and cultural values" [24]. The main objectives are to develop sustainable tourism based on the minimization of negative impact and the maximization of positive impact at the social, cultural, ecologic, and economic levels $[25,26]$.

Along with the natural attractions, the cultural resources are considered very important due to their contribution to the social coherence of the communities [27]. Thus, the cultural tourism activities stimulate the preservation of the natural and cultural heritage [28]. Finally, both nature and culture motivations of ecotourism activities may contribute to the sustainable development of the local community [29].

As regards the profile of visitors to ecotourism destinations around the world, the main findings in the literature are presented in Table 1.

Table 1. Previous studies about visitors' profile and motivations from several world destinations (America, Australia, New Zeeland, Asia, Europa, and Africa).

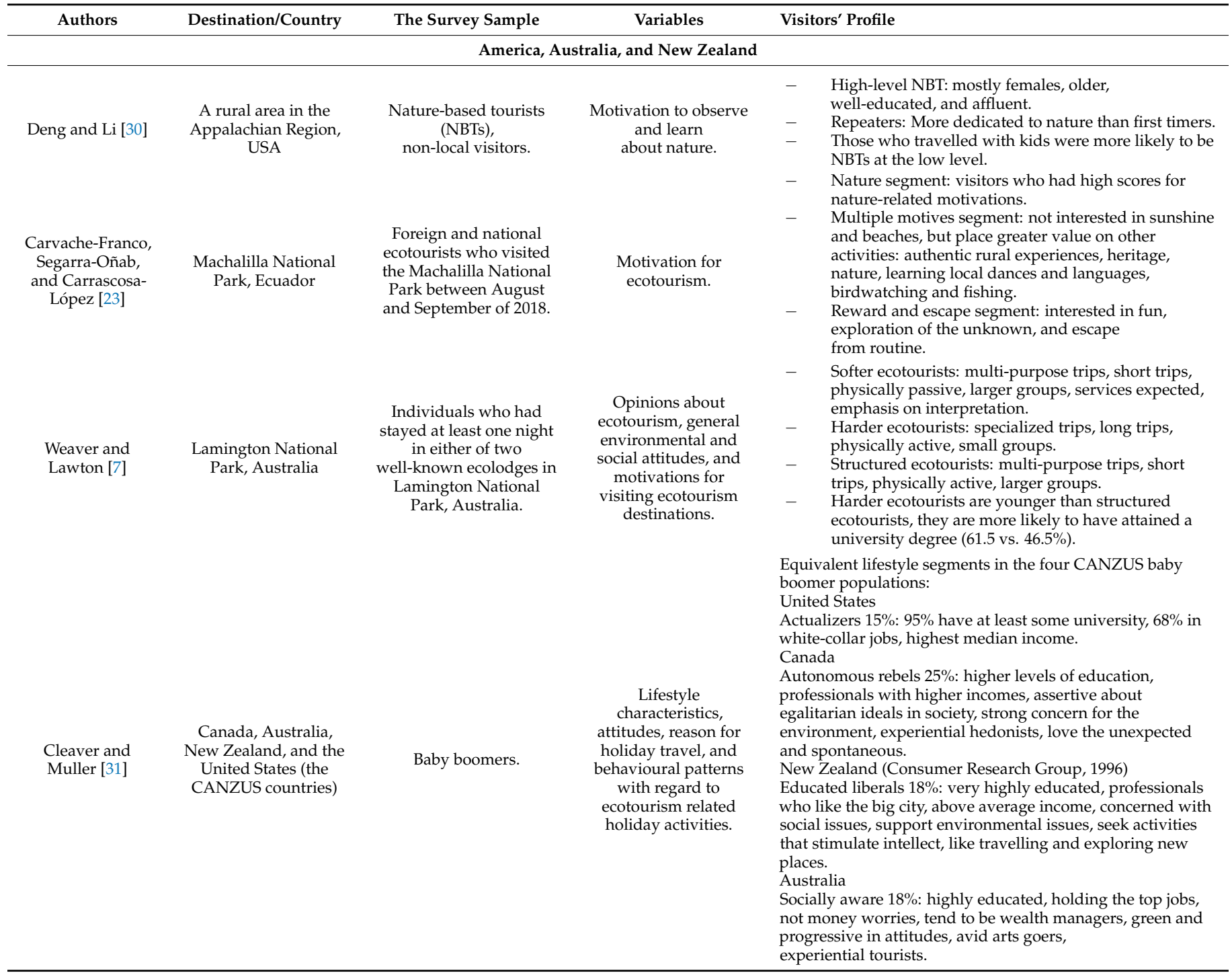


Table 1. Cont.

\begin{tabular}{|c|c|c|c|c|}
\hline Authors & Destination/Country & The Survey Sample & Variables & Visitors' Profile \\
\hline \multicolumn{5}{|c|}{ Asia } \\
\hline Gu et al. [32] & $\begin{array}{c}\text { Changbai Mountain } \\
\text { Biosphere Reserve } \\
\text { (CMBR), } \\
\text { China }\end{array}$ & $\begin{array}{l}\text { Domestic visitors to the } \\
\text { CMBR. }\end{array}$ & Visit motivations. & 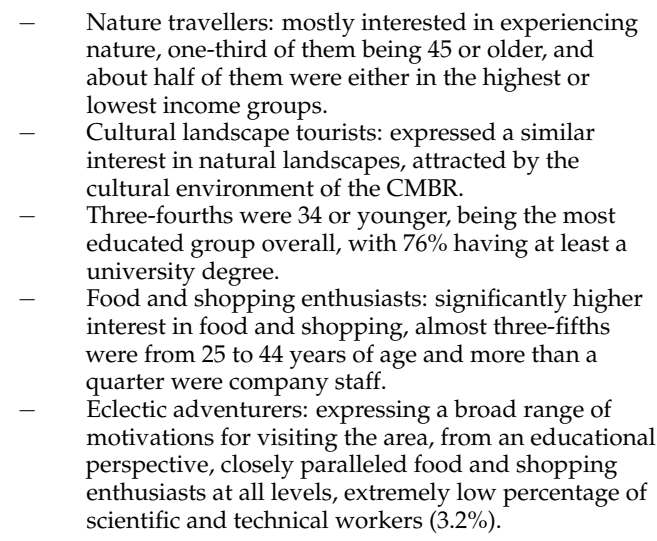 \\
\hline $\begin{array}{l}\text { Sheena, Mariapan, } \\
\text { and Aziz [33] }\end{array}$ & $\begin{array}{l}\text { Kinabalu Park, Sabah, } \\
\text { Borneo, Malaysia }\end{array}$ & $\begin{array}{c}\text { The domestic Malaysian } \\
\text { ecotourists. }\end{array}$ & $\begin{array}{l}\text { Ecotourists' trip } \\
\text { characteristics; their } \\
\text { expectations towards } \\
\text { services and } \\
\text { preferences for } \\
\text { arranged travel. }\end{array}$ & $\begin{array}{ll}\text { - } & \text { Hard ecotourists }(40 \%) \text { : autonomous in their travel } \\
\text { arrangements. } & \text { Structured ecotourists (27.5\%). } \\
- & \text { Soft ecotourists (33.3\%), who expected services } \\
\text { during their trip and made arrangements via } \\
\text { travel agents. }\end{array}$ \\
\hline
\end{tabular}

\section{Europe}

Hornoiu,

Pădurean, Nica, and Maha [22] Retezat,

Piatra Craiului,

Vânători-Neamț and

Maramureş

Mountains)

Ten ecological farms in the Aegean Region Turkey

Adalilar et al. [34]

Pintassilgo,

Matias, and

André [35]

Kim and

Weiler [36]

Derek, Woźniak, and Kulczyk [37]

The Great Masurian
Lakes,

Lakes,
Poland
Algarve, a typical sun and beach destination Portugal

Charmouth coastal area, South

West of England,

Great Britain
English-speaking day visitors aged 18 and over.
Domestic and foreign consumers in Turkey regarding eco-villages.

Tourists older than

15 years

old, only on person from each family.
Consumer perceptions, attitudes, and preferences regarding eco-villages.

Tourist attitudes towards an accommodation tax for environmental protection in the Algarve.

Visitors' attitudes towards an environmentally responsible tourist behaviour.

Domestic visitors in nine towns or villages throughout the area particularly interesting for sailors.

40 individuals using the messenger of a social network.

The destination image of Bucovina among the Romanian tourists.
The young tourist chooses, in order of preference: ecotourism, nature tourism, rural tourism, cultural tourism, and adventure tourism

Additionally, the consumer's preferred tourism activities are, in decreasing order, photography, landscape painting, studying the flora and fauna, cultural sightseeing, and hiking.

Most of the respondents (53;8\%) are in the 35-54 age group, most of them married $(56.9 \%)$ and college graduates $(76.9 \%)$

Seventy-nine percent of the respondents had some

knowledge about the eco-villages. The majority of people $(84.5 \%)$ who had some degree of knowledge were between $35-54$ years old.

Country: Turkey (53.6\%), Europe (34.3\%), and Northern America (12.1\%).

A large proportion of tourists are British $(40.6 \%)$, aged between 37 and 45 years old (30.2\%) or older than $55(30.4 \%)$, with secondary $(43.6 \%)$ or college education degrees $(43.4 \%)$ Landscape $(58.1 \%)$ and proximity $(33.9 \%)$ were the main determinants of beach choice

Two distinct groups of tourists: prefer traditional beach recreations $(89.8 \%)$ or prefer other activities, such as walking on the beach $(10.2 \%)$.

Dominant profile: female, 36 and 55 years old, having university degree.

$64 \%$ of respondents were revisiting the Charmouth coastal area, and $45 \%$ had visited natural areas 10 or more times in the past.

Travel motivations: "relaxing and having fun with family/friends" (56\%), "enjoying the beauty of nature" $(23 \%)$, "learning about fossils" (15\%), and "doing physical exercise/leisure activities" (6\%).

Two segments: tourists with "high environmental attitude" or with "low environmental attitude".

Six clusters were identified: angling sailors: university degrees, between 25 and 34 years old, living mostly in smaller towns non-angling sailors: living in larger cities cyclists: young people (18-24 years old) living in large cities anglers: live in villages and small towns water re-creationists passive tourists: university degrees, 35-44 years old.

Education: $43.2 \%$ have a graduate degree, and $40.2 \%$ have a higher degree.

Age: range between 26 and 40 years old
$62.2 \%$ of respondents were married, $29.7 \%$ were single.

Additionally, $75.7 \%$ of the respondents were women and $24.3 \%$ men. 
Table 1. Cont.

\begin{tabular}{|c|c|c|c|c|}
\hline Authors & Destination/Country & The Survey Sample & Variables & Visitors' Profile \\
\hline \multicolumn{5}{|c|}{ Africa } \\
\hline $\begin{array}{c}\text { Saayman and } \\
\text { Slabbert [39] }\end{array}$ & $\begin{array}{c}\text { The Kruger National } \\
\text { Park/South Africa }\end{array}$ & $\begin{array}{l}\text { Local and non-local } \\
\text { visitors. }\end{array}$ & $\begin{array}{l}\text { Demographic, } \\
\text { socio-economic, } \\
\text { geographic, and } \\
\text { psychographic profile. }\end{array}$ & $\begin{array}{l}\text { Demographic profile: in both years, the respondents are } \\
\text { mostly married, Afrikaans speaking tourists who travel in } \\
\text { groups of approximately three people and have a } \\
\text { professional occupation. } \\
\text { Socio-economic profile: most of the tourists were well } \\
\text { educated. } \\
\text { Geographic profile: tourists who visited this park were } \\
\text { mainly South Africans who reside in the Gauteng province. } \\
\text { Psychographic profile: more than } 50 \% \text { of the tourists in both } \\
\text { surveys indicated that they had visited one of the national } \\
\text { parks on average three times per year. }\end{array}$ \\
\hline $\begin{array}{c}\text { Nheta, } \\
\text { Madzunyea, and } \\
\text { Tshipala [40] }\end{array}$ & $\begin{array}{c}\text { The Capricorn District } \\
\text { Municipality/South } \\
\text { Africa }\end{array}$ & $\begin{array}{l}\text { The study population } \\
\text { consisted of tourists and } \\
\text { visitors found within the } \\
\text { Capricorn District } \\
\text { Municipality. }\end{array}$ & $\begin{array}{l}\text { Relationship between } \\
\text { age, occupation, } \\
\text { gender, income, } \\
\text { household status, } \\
\text { education, and } \\
\text { ecotourism behaviour. }\end{array}$ & $\begin{array}{l}\text { - Statistically significant relationship between } \\
\text { education and being an ecotourist. } \\
\text { The number of ecotourists in the age group of } 18-24 \\
\text { years was approximately } 6 \% \text { higher than } \\
\text { normal tourists. } \\
\text { As for the age group of } 35+\text { years, it also indicated a } \\
\text { positive representation of ecotourists that exceeded } \\
\text { normal tourists by approximately } 12 \% \text {. } \\
\text { Female } 37.4 \% \text { and male } 24.8 \% \text { indicated as } \\
\text { being ecotourists. } \\
\text { The self-employed occupational group is highly } \\
\text { significant in influencing one to become } \\
\text { an ecotourist. }\end{array}$ \\
\hline Amuquandoh [42] & Nigeria & $\begin{array}{l}\text { The population for the } \\
\text { study was the ecotourists } \\
\text { to the parks as at the } \\
\text { time of the study } \\
\text { (October } 2008 \text { to May } \\
2009 \text { and October } 2009 \text { to } \\
\text { May 2010). }\end{array}$ & $\begin{array}{l}\text { Gender, marital status, } \\
\text { income, household, } \\
\text { religion, loyalty, } \\
\text { nationality, members } \\
\text { of environmental } \\
\text { non-governmental, } \\
\text { organisations (NGOs), } \\
\text { profiles, trip } \\
\text { characteristics, } \\
\text { motivations of } \\
\text { ecotourists. }\end{array}$ & $\begin{array}{l}\text { Ecotourist profile: } 74.6 \% \text { of the sampled respondents were } \\
\text { between } 21 \text { and } 40 \text { years old with a mean age of } 31.1 \text { years; } \\
70.0 \% \text { were male, while } 29.1 \% \text { were female; more than half } \\
\text { of the respondents ( } 58.6 \% \text { ) were single, and } 41.4 \% \text { were } \\
\text { married. About } 82.6 \% \text { of the ecotourists had household } \\
\text { sizes of } 1 \text { to } 5 \text { members. In terms of education, } 50.6 \% \text { of } \\
\text { them had a bachelor's degree/higher national diploma. } \\
\text { Most ecotourists }(61.1 \% \text { ) had professional/management } \\
\text { occupation, while } 38.9 \% \text { were students. } 92 \% \text { of the } \\
\text { ecotourists were Nigerians, about } 4.8 \% \text { were Britons, } 2.1 \% \\
\text { were Americans, and } 1.1 \% \text { were French. Around } 32.0 \% \text { of } \\
\text { the respondents were members of environmental } \\
\text { non-governmental organisations (NGOs) and } 82.0 \% \text { of the } \\
\text { travellers visited the area several times, which is an } \\
\text { indicator that they are experienced ecotourists. } \\
\text { Profile of the tourists: single (66\%); female (58\%); had } \\
\text { finished either a first degree ( } 56 \% \text { ) or postgraduate } \\
\text { education ( } 21 \% \text { ). } \\
\text { Places of origin: Europe (59\%), North America ( } 20 \%) \text {, Africa } \\
\text { ( } 9 \%) \text {, Asia ( } 7 \% \text { ), Scandinavia ( } 6 \%) \text {, and Oceania ( } 0.3 \%) \text {. The } \\
\text { major reasons for visiting Kakum National Park can be } \\
\text { summarized into four general categories: adventure, } \\
\text { education, escape and relaxation, or sociability. }\end{array}$ \\
\hline
\end{tabular}

According to the studied literature, visitors' motivations were significantly different depending on the continent that they travelled to. Some visitors chose America as a destination because they wanted to observe nature and learn about it, to have authentic rural experiences, to learn local dances and languages, for birdwatching and fishing, to have fun, to explore the unknown and to escape from their daily routine. Visitors to Asian ecotourism destinations were looking to have natural and cultural environmental experiences, to integrate in their travel experience distinctive elements such as food and shopping, and were willing to forget the usual comfort of tourism services. Visitors who wanted multi-purpose and specialized trips visited Australia. Europe has the best destinations for photography, landscape painting, studying the flora and fauna, cultural sightseeing, and special guided hikes. The visitors who chose destinations in Africa were interested in adventure, education, escape from their daily routine, relaxation, and socialization with the local people.

The study of Nheta et al. [40] has shown a statistically significant relationship between education and being an ecotourist for the visitors that made a trip to the Capricorn District (South Africa). Another interesting finding was that the younger tourists who decided to visit Romania had chosen some activities included in the travel package, such as practicing ecotourism, nature tourism, rural tourism, cultural tourism, and adventure tourism [22]. 
Wight [43] discovered that from 70 of the variables included in the studies carried out in order to understand what motivates tourists to go on a trip, only 25 referred to the intrinsic motivations regarding the destination's characteristics. So, visitors are more likely to choose a destination that reflects their preferences, matching their individual perceptions about the destination. In fact, there is an obvious lack of understanding (there is no clear theoretical approach in order to understand the tourists' motivations, as mentioned by Fodness [44]) as to why visitors decide to visit a tourism destination, especially when they claim that they are interested in nature-based experiences.

\section{The Presentation of the Ecotourism Destinations Included in the Research}

The Romanian National Tourism Authority [45] define the ecotourism destination as a tourism destination that respects the following principles: (1) the destination projects a responsible marketing image; (2) businesses with a sustainable management predominate in the destination; (3) there is a real support for local communities within the destination; (4) tourists and locals are made aware of and informed about the natural characteristics of the destination; (5) clear nature conservation measures are implemented within the destination.

The ecotourism destination includes at least a protected area and the local communities around or within it, including the protected area administrator in the management of the whole destination. The management of the destination focuses on tourism products, small-scale infrastructure development, and marketing having sustainability and nature conservation as core values. The nature conservation objectives of the protected area are integrated in the overall tourism management plan of the destination. Therefore, the ecotourism destination is a model of local sustainable development based on ecotourism [46].

The above definition is in line with Buhalis [47], who define a tourism destination as "that area clearly delimited from a geographical point of view, perceived by tourists as a distinct/independent entity and which has a unitary legislative and political framework". It can vary in size from whole continents to countries, provinces, and resorts [48].

In 2012, the Ministry of Regional Development and Tourism of Romania, in partnerships with the National Institute for Research and Development in Tourism (INCDT) and the Association of Ecotourism in Romania (AER), developed the framework for evaluating and certifying ecotourism destinations in Romania [16]. This initiative is based on the recommendation of the World Tourism Organization to use the European Ecotourism Labelling Standards (EETLS) [49], developed and refined in the frame of several EU funded projects as part of the [50]. By adopting this framework, destinations that meet the criteria are awarded with the title of "ecotourism destinations", and they will be included in the national tourism promotion campaigns, targeting the domestic and foreign markets [46]. There are ten ecotourism destinations developed and promoted by AER in Romania. The present study focuses on four of them that were selected because they can ensure accurate data collection. As they are located in different geographical areas of the country (see Figure 1), they were considered appropriate for the purpose of this research. The ecotourism destinations included in the research are presented in red, as follows. 


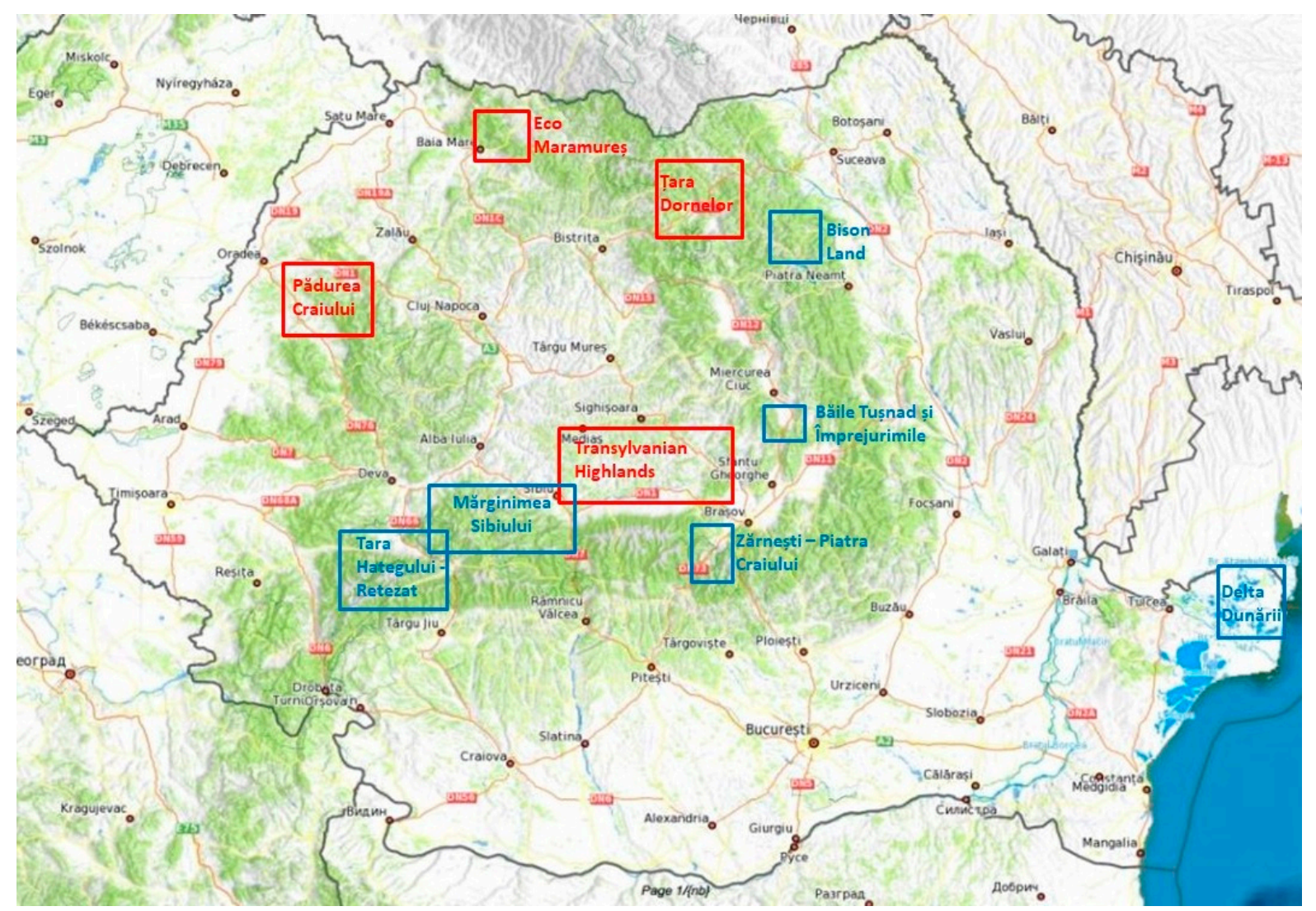

Figure 1. The geographical distribution of the Romanian ecotourism destinations. Source: [46].

\section{Pădurea Craiului}

The destination is situated in the Western Carpathians, with large areas of Karst landscape: caves, gorges, and plateaus. The profile of the destination is a mix of naturebased and cultural activities, with a focus on families and children as its market segment. The proximity of two large Romanian cities makes it mostly a one-day destination, so the efforts of the destination management organization are on developing infrastructure and attractions in order to convince its visitors to extend their stay. Because of this, the accommodation infrastructure is poorly developed, with only 33 accommodations and 729 beds.

\section{Transylvanian Highlands}

Located in the centre of the country, it overlaps with the second largest Natura 2000 site in Romania. This area in southern Transylvania is known for its Saxon cultural heritage, and the identified unique selling proposition is the last medieval landscape of Europe. Although the destination is known mainly due to cultural attractions (fortified churches, preserved medieval villages, fortresses and mansions, traditional cultural landscape), the destination also has a rich natural heritage represented by avifauna, meadows of high conservation value, meadows with secular oaks, etc., and an impressive cycling infrastructure with more than $500 \mathrm{~km}$ of trails. It is the largest of the four destinations included in the study, and it offers 82 registered accommodation units with a total of 1421 beds.

\section{Eco Maramures}

This is a small destination situated in Maramures county, in the north of Romania. The area is known for the wood carving civilization; therefore, it has a wide range of cultural attractions and activities. It differentiates from the rest of Maramures by including nature-based activities and infrastructure (hiking and cycling trails, thematic trails, and others), and it is promoted under the image of the "green heart of historic Maramureș". Although it is a small area, the accommodation capacity totals 1805 beds in 134 units. 


\section{Țara Dornelor}

The destination is in the north of the country and partially overlaps the Călimani National Park. The uniqueness characteristic is given by the well-preserved volcanic landscape and the active character of the destination, the area being excellent for a varied range of nature-based activities. This area has a long-standing tradition in Romanian tourism, especially due to the Vatra Dornei spa resort, which acts as a service hub for the destination. This fact is also reflected in the accommodation capacity at the destination level, which totals 4692 places in 227 accommodation units.

\section{Research Methodology}

The present research is part of the efforts made by AER to develop and to professionalize the network of ecotourism destinations in Romania, with the support of the RomanianAmerican Foundation, the Romanian Partnership Foundation, and the Swiss-Romanian Cooperation Programme. AER coordinates and offers technical tourism assistance to a network of local NGOs that act as destination management organizations. The aim of the research was to gather valuable data regarding visitors' and destination profile that will then help the management teams in planning their management and marketing activities.

The data were gathered over a period of an entire year and consisted of direct interviews with visitors, based on a questionnaire. The data contain a range of closed questions aimed at reaching the goals of the abovementioned research. The measurement scales used for questions design are mainly nominal and 5-level Likert scales at equal distances. Nevertheless, for the purpose of this article, only eight categorical variables have been considered (see Table 2).

Table 2. The variables used in the research.

\begin{tabular}{cc}
\hline Variable & Response Categories \\
\hline Age & Under 18 years; 18-29 years; 30-50 years; 51-65 years; over 65 years \\
Monthly income & Under EUR 215; EUR 215-430; EUR 431-645; EUR 646-1077; over EUR 1077 \\
Education & Lower-secondary education; upper and post-secondary education; higher education \\
Occupation & Active people (employee, self-employed); retired; inactive people (students, without \\
occupation, etc.) \\
Romania; other countries \\
$\begin{array}{c}\text { Country of residence education } \\
\text { Visit purpose } \\
\text { Visit frequency }\end{array}$ \\
Ecotourism destination & Nature purpose; culture purpose; leisure purpose; other activities \\
First visit; many times per year; once a year; every few years
\end{tabular}

* The income levels were expressed in the Romanian currency and converted into EUR.

The methodology of data collection included identifying the interview spots in each destination, as well as the days in which the interviews were performed. There were randomly chosen days within the season, as well as during the off-season, during the week and the weekend. In order to prevent data alteration, the application of the questionnaires was avoided in accommodation units or on the occasion of events. The main aim of this methodology was to identify the characteristics of the visitors that visit the ecotourism destinations in different seasons and during the entire week period.

The questionnaires were applied with the help of voluntary interview operators who were previously trained within a session of face-to-face teaching. The data gathering was accomplished using an application developed for Android smartphones. It was able to store data directly into an online database that could then be exported in Excel format, which allowed the researchers to check for inconsistencies between answers. It also facilitated the data transfer and processing into other data processing system (such as SPSS). At the same time, the app stamped each questionnaire with the GPS coordinates, where it was filled in. This proved that each volunteer collected the data at the designated locations, which ensured the validity of the data. 
The data were collected from a sample of 1157 visitors from the above mentioned ecotourism destinations: 363 people (31.4\%) from Eco Maramures, 237 people (20.5\%) from Tara Dornelor, 355 people (30.7\%) from Pădurea Craiului, and 202 people (17.5\%) from the Transylvanian Highlands. The data from Excel files were taken into the SPSS system and processed by using univariate and bivariate analyses. The statistical significance of the differences between the segments of visitors was tested with the Chi-square test. The aim of these analyses is to find answers to the following research question: "Which are the profiles of the main segments of visitors in the studied ecotourism destinations?" A number of eight categorical variables were considered in this research. They are related to the demographic and travel characteristics of the visitors. The variables and their response categories are presented in Table 2.

A segmentation based on the a priori approach from a single characteristic has been computed [30]. Four segments were identified according to the answers given by respondents to a question, which contains a single-choice list of motivations to visit the destination: skiing, ice climbing, rafting, hiking, ziplining, mountain biking, flora and fauna observation, culture and traditions, visit painted churches, relaxing in the guesthouse courtyard, visit friends and relatives, secondary residence, health treatment, team building, or other activities. These segments were labelled as follows: nature travellers; culture travellers; leisure travellers, and eclectic travellers. The labels were established in line with other research and adapted to the present context [23,32,51].

By applying bivariate analyses, the profile of visitors in the analysed Romanian ecotourism destinations was designed. The results were computed from the valid cases of every question by excluding missing answers. Furthermore, the profiles of the four mentioned segments according to the purpose of the visit have been computed. The differences between the subgroups resulted according to the demographic and travel characteristics could be considered statistically significant, as in all cases, the p-value is lower than 0.05. Finally, the dominant profile of each segment was summarized in an intuitive graphical representation and discussed in relationship with the relevant literature.

\section{Results}

Taking into account the first objective of the research to identify the demographic and travel characteristics of visitors to the main ecotourism destinations in Romania (O1), the results based on the responses to the questionnaire are presented in Table 3. Most of the interviewed subjects are active people $(77.5 \%)$, with a medium income $(32.7 \%)$ and higher education $(70.8 \%)$, aged between $30-50$ years old $(56.2 \%)$. As regards the country of residence, the majority of visitors are Romanians $(79.9 \%)$, while international visitors represent $20.1 \%$ of the total sample. As to the ratio of visitors according to their country of residence, the structure is similar to the official statistics about the visitors' provenance in the main tourist destinations of Romania ( $80 \%$ domestic, $20 \%$ international) [52].

Table 3. The profile of visitors to Romanian ecotourism destinations.

\begin{tabular}{lcc}
\hline & Characteristics & $\%$ \\
\hline Age & Under 18 years & $1.6 \%$ \\
18-29 years & $20.5 \%$ \\
30-50 years & $56.2 \%$ \\
51-65 years & $17.8 \%$ \\
Over 65 years & $3.9 \%$ \\
Under EUR 215 & \\
EUR 215-430 & $5.2 \%$ \\
EUR 431-645 & $19.9 \%$ \\
EUR 646-1077 & $32.7 \%$ \\
Over EUR 1077 & $23.0 \%$ \\
\end{tabular}


Table 3. Cont.

\begin{tabular}{cc}
\hline \multicolumn{1}{c}{ Characteristics } & $\%$ \\
\hline Education & $1.7 \%$ \\
Lower-secondary education & $27.5 \%$ \\
Upper and post-secondary education & $70.8 \%$ \\
Higher education & $77.5 \%$ \\
Occupation $\quad$ Active people & $12.8 \%$ \\
Retired & $9.7 \%$ \\
Country of residence people (students, without occupation, & \\
$\quad$ Romania & $79.9 \%$ \\
Other country & $20.1 \%$ \\
\hline
\end{tabular}

The visitors in the abovementioned sample were segmented into four categories according to their travel purpose $(\mathrm{O} 2)$. In this respect, four visitor segments were computed: nature travellers $(41.7 \%)$, culture travellers $(29.5 \%)$, leisure travellers $(15.0 \%)$, and eclectic travellers $(13.8 \%)$. Nature travellers are active people that visit the ecotourism destinations in order to do sports (skiing, ice climbing, rafting, hiking, ziplining, mountain biking, etc.) or to observe flora and fauna. Culture travellers are mainly interested in learning more about culture and traditions and in visiting painted churches or other heritage-based attractions. Leisure travellers are oriented towards soft activities such as relaxing in the guesthouse courtyard or at their secondary residence, visiting friends or relatives, etc. Eclectic travellers are mainly in transit or visit the destinations with various other purposes, which are not included in the above mentioned categories.

The third research objective (O3) was to identify the repetitive visiting behaviour to the ecotourism destinations of the identified segments. The results presented in Table 4 reveal that most of the respondents (45.3\%) are at their first visit in the four ecotourism destinations. Another $22.8 \%$ visit the destination many times per year, $16.8 \%$ once a year, and $15.1 \%$ every few years. Taking into consideration this behaviour in relation to the visit purpose, it is observed that by excluding the first visit travellers, who represent most of the respondents in all categories, nature travellers visit the destination many times per year $(29.4 \%)$, culture travellers visit the destination mainly every few years $(12.6 \%)$, leisure travellers revisit the destination mainly once a year $(25.6 \%)$, while eclectic visitors usually go many times per year (34.4\%).

Table 4. The relationship between visit frequency and visit purpose $\%$ within columns total.

\begin{tabular}{cccccc}
\hline $\begin{array}{c}\text { Visit Frequency in } \\
\text { Destination }\end{array}$ & Nature Travellers & Culture Travellers & Leisure Travellers & Eclectic Travellers & Chi-Square \\
\hline First visit & $39.6 \%$ & $66.8 \%$ & $32.0 \%$ & $31.2 \%$ & 123.08 \\
Many times per year & $29.4 \%$ & $10.3 \%$ & $18.6 \%$ & $34.4 \%$ & 0.00 \\
Once a year & $17.9 \%$ & $10.3 \%$ & $25.6 \%$ & $17.8 \%$ & \\
Every few years & $13.1 \%$ & $12.6 \%$ & $23.8 \%$ & $16.6 \%$ & \\
Total & $100.0 \%$ & $100.0 \%$ & $100.0 \%$ & $100.0 \%$ & \\
\hline
\end{tabular}

The differences in behaviour patterns between the groups resulting from the main purpose of their visit are statistically significant in relation to the visit frequency given to the results of the Chi-square test for bivariate analysis (Chi square $=123.08, p$ value $=0.00$ ). In conclusion, the visit purpose determines tourists' return to the analysed ecotourism destinations.

As to the profile of the different visitor segments regarding their dominant demographic characteristics (O4), significant relationships were also found between the travel purpose and the main demographic characteristics. The Chi-square test for bivariate analysis returned p-values smaller than 0.05 for all cross tabulations included in Table 5 . 
Table 5. The profiles of the visitors segments according to the demographic characteristics \% within rows total.

\begin{tabular}{|c|c|c|c|c|c|c|}
\hline Characteristics & Nature Travellers & $\begin{array}{l}\text { Culture } \\
\text { Travellers }\end{array}$ & Leisure Travellers & Eclectic Travellers & Chi-Square & $p$-Value \\
\hline \multicolumn{7}{|l|}{ Age } \\
\hline Under 18 years & $61.1 \%$ & $11.1 \%$ & $11.1 \%$ & $16.7 \%$ & 79.039 & 0.00 \\
\hline 18-29 years & $51.9 \%$ & $23.4 \%$ & $9.8 \%$ & $14.9 \%$ & & \\
\hline $30-50$ years & $44.0 \%$ & $28.8 \%$ & $12.6 \%$ & $14.6 \%$ & & \\
\hline 51-65 years & $26.5 \%$ & $38.7 \%$ & $27.9 \%$ & $6.9 \%$ & & \\
\hline Over 65 years & $17.8 \%$ & $44.4 \%$ & $22.2 \%$ & $15.6 \%$ & & \\
\hline \multicolumn{7}{|l|}{$\begin{array}{l}\text { Monthly } \\
\text { income }\end{array}$} \\
\hline Under EUR 215 & $64.9 \%$ & $13.5 \%$ & $16.2 \%$ & $5.4 \%$ & 51.32 & 0.00 \\
\hline EUR 215-430 & $45.1 \%$ & $16.2 \%$ & $26.1 \%$ & $12.7 \%$ & & \\
\hline EUR 431-645 & $53.6 \%$ & $20.2 \%$ & $18.0 \%$ & $8.2 \%$ & & \\
\hline EUR 646-1077 & $47.0 \%$ & $32.3 \%$ & $12.2 \%$ & $8.5 \%$ & & \\
\hline Over EUR 1077 & $36.5 \%$ & $43.8 \%$ & $13.9 \%$ & $5.8 \%$ & & \\
\hline \multicolumn{7}{|l|}{ Education } \\
\hline $\begin{array}{c}\text { Lower- } \\
\text { secondary } \\
\text { education } \\
\text { Upper and }\end{array}$ & $50.0 \%$ & $16.7 \%$ & $22.2 \%$ & $11.1 \%$ & 84.29 & 0.00 \\
\hline $\begin{array}{l}\text { post-secondary } \\
\text { education }\end{array}$ & $34.6 \%$ & $17.3 \%$ & $24.4 \%$ & $23.7 \%$ & & \\
\hline $\begin{array}{c}\text { Higher } \\
\text { education }\end{array}$ & $44.7 \%$ & $34.2 \%$ & $12.2 \%$ & $8.8 \%$ & & \\
\hline \multicolumn{7}{|l|}{ Occupation } \\
\hline Active people & $43.8 \%$ & $29.5 \%$ & $13.8 \%$ & $12.9 \%$ & 50.52 & 0.00 \\
\hline Retired & $21.0 \%$ & $42.0 \%$ & $26.6 \%$ & $10.5 \%$ & & \\
\hline Inactive people & $56.9 \%$ & $17.4 \%$ & $10.1 \%$ & $15.6 \%$ & & \\
\hline \multicolumn{7}{|l|}{$\begin{array}{l}\text { Country of } \\
\text { residence }\end{array}$} \\
\hline Romania & $45.2 \%$ & $23.3 \%$ & $17.2 \%$ & $14.3 \%$ & 93.60 & 0.00 \\
\hline Other countries & $27.8 \%$ & $55.7 \%$ & $7.0 \%$ & $9.6 \%$ & & \\
\hline \multicolumn{7}{|l|}{$\begin{array}{l}\text { Ecotourism } \\
\text { destination }\end{array}$} \\
\hline Eco Maramureș & $14.3 \%$ & $48.8 \%$ & $14.3 \%$ & $22.6 \%$ & 668.42 & 0.00 \\
\hline Tara Dornelor & $44.3 \%$ & $13.5 \%$ & $39.2 \%$ & $3.0 \%$ & & \\
\hline $\begin{array}{l}\text { Pădurea } \\
\text { Craiului }\end{array}$ & $82.0 \%$ & & $3.1 \%$ & $14.9 \%$ & & \\
\hline $\begin{array}{c}\text { Transylvanian } \\
\text { Highlands }\end{array}$ & $16.8 \%$ & $65.3 \%$ & $8.9 \%$ & $8.9 \%$ & & \\
\hline
\end{tabular}

The results presented in Table 5 are computed in percentages calculated by reporting the absolute frequencies to the totals of table rows in order to obtain comparable figures. In Table 5, we can observe that the majority of people aged below 50 years old visit the ecotourism destination for nature purposes, while people over 50 years visit it for culture purposes. Regarding the dominant characteristics of the analysed segments, the nature travellers are young people (aged under 30 years old), culture travellers are mainly 65+ years old, leisure travellers are between 51-65 years old, and eclectic travellers are under 18 and over 65 years old.

As regards the income, most of the respondents with low and middle incomes (up to EUR 1077) travel for nature purposes, while those with high incomes have mainly culture purposes. The dominant income categories for the named segments are: very low income 
(under EUR 215) for nature travellers, high income (over EUR 1077) for culture travellers, and low income (EUR 215-430) for leisure and eclectic travellers.

From an education point of view, most of the respondents in all categories visit the destination for nature purposes, but the dominant characteristic for nature travellers is lower-secondary education, for culture travellers, it is higher education, and uppersecondary for leisure and eclectic travellers. According to the occupation, most of active and inactive people travel for nature purposes, while the retired persons for culture purposes. Inactive people are the dominant group for nature and eclectic travellers and retired people for cultural and leisure travellers. Finally, as regards the country of residence, Romanians prefer nature activities, being the dominant group in this segment, and foreign visitors prefer cultural activities.

Even if the ecotourism destination in which data were collected is not a characteristic of the visitors, the results of cross-tabulation analysis reveal interesting aspects about the main activities sought out by visitors. Thus, in Pădurea Craiului and Țara Dornelor, most visitors go for nature purposes, while in Eco Maramures and the Transylvanian Highlands, they go for culture purposes. The majority of leisure travellers were found in Tara Dornelor, and the most eclectic travellers were in the Eco Maramureș destination.

\section{Discussions, Conclusions, and Implications}

People visit various tourism destinations in order to fulfil their objectives, to satisfy their needs and curiosities, to be included in a specific social group, and so on. When it comes to choosing a destination, a series of interactions between perceptions of that destination and the personal reasons of the trip occur. The value of an ecotourism destination consists in the meaning that it gives to the visitors, and this can vary from the engagement with the nature to interactions with other people.

The main purpose of this study was to identify the profile of visitors to four ecotourism destinations from Romania, considering the ecotourism potential of this country and the fact that there are very few empirical studies regarding these ecotourism destinations. Starting from the visitors' segmentations based on the main purpose of their visit and continuing with the analysis of other socio-demographical and travel characteristics, we are convinced that this profile is useful for destination marketers and managers. We also consider that maintaining under control the number of visitors and targeting some narrow segments could contribute to a sustainable development of the studied ecotourism destinations.

The research findings provided us with valuable information about the profiles of the visitors to the four studied ecotourism destinations from Romania. The profiles of the four segments of visitors, according to the main visit purpose, are presented in Figure 2. They are based on the dominant characteristic obtained for every demographic variable. For managerial reasons, other characteristics have been selected when the differences from the dominant group are considered quite small. As from a statistical perspective the differences are globally significant, the abovementioned associations were made on logical judgment in order to help the decision makers in the segmentation process based on these profiles.

The research results reveal that the visitors to Romanian ecotourism destinations are middle-aged, with middle income and higher education, and they visit the destination several times a year. This profile is in line with certain findings highlighted in the tourism literature for several places around the world: Africa, America, New Zeeland, and Australia [23,30,39,41,42]. The main segment identified within the present paper, nature travellers, includes visitors under 50 years old, with low and middle income and having secondary education level. This finding is not in line with the profile found in USA, excepting the repetitive visit behaviour [30]. Culture travellers are another important segment of visitors to Romanian ecotourism destinations. They are over 50 years old, with a high income, being highly educated and retired. The results show that more international visitors than Romanians are motivated to visit the analysed destinations for cultural purposes. These findings are partially contrary to the ones from China, where culture travellers are mainly young people with a low income [32]. Leisure travellers prefer soft activities, 
mainly around the accommodation. They are over 50 years old, with a low income, having a secondary education and being retired. Eclectic travellers are mainly Romanian visitors, under 50 years old, with a low income, and a secondary education level. The general profile of the visitors in the studied ecotourism destinations has three characteristics: the age between 30-50 years old, middle income, and high education level. Those visitors have a broad range of visit purposes that are not focused on specific activities in the ecotourism destination, being similar to the eclectic adventurers identified in the literature [32].

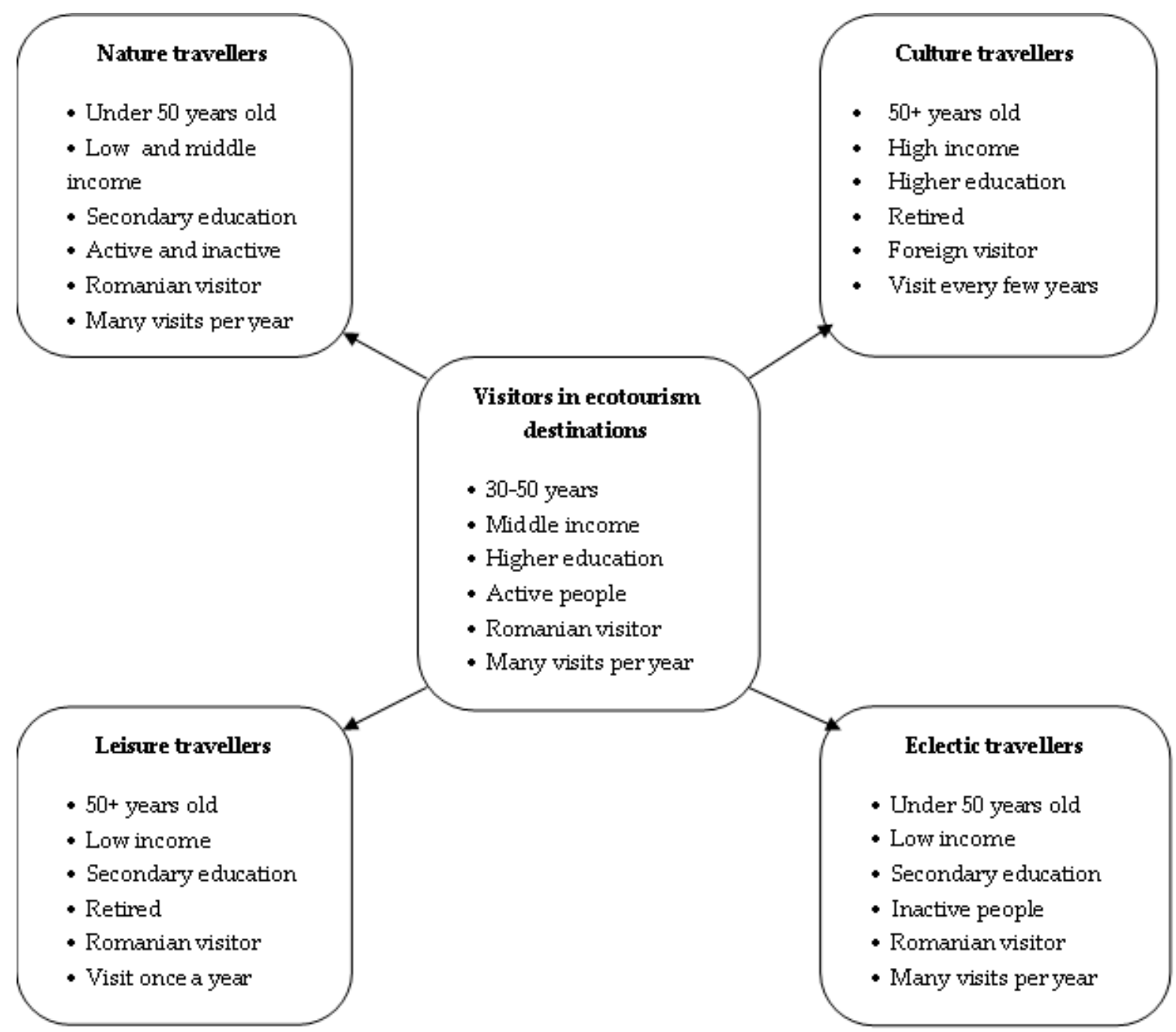

Figure 2. The main visitor segments and their profiles according to the demographic and travel characteristics.

In our opinion, nature and culture travellers are the most attractive visitor segments of an ecotourism destination, which can be targeted using tailored management and marketing strategies. Thus, the results of our research have strong implications for the ecotourism destination management and marketing. The highlighted profile can help destination management organizations (DMOs) to better understand who their visitors are in order to make proper decisions meant to ensure a sustainable development on three pillars: (1) protection of the natural sites and avoidance of excessive pollution, (2) protection of local communities against destination over-crowding, and (3) local economic growth in different fields in order to avoid mono-industry dependence.

The information regarding age, income, and occupation, correlated with education, can help DMOs to develop new tourism products and experiences, in accordance with the visitors' profile. It enables them to craft meaningful messages and adapt their promotion 
materials to meet their market segments expectations. By comparing the visitors' profile with the existing tourism infrastructure and service offers, some of the weaknesses and strengths of the destination can be discovered (for example, if in a destination most of the visitors spend money on fuel or there is overcrowding, it could be due to the lack of local public transport, which should be addressed together with the local authorities). Additionally, the DMOs should be aware of the necessity to have up-to-date statistical data about their visitors' profile and to measure the impact of their management activities and the overall performance progress of the destination. Such data could be obtained through the support of academic institutions as well as non-profit organisations.

\section{Limitations and Future Research}

The research was conducted throughout a year in all seasons including weekdays and weekends. Even if the days of data collection were randomly selected, the participation in the survey was on a voluntary basis. This selection method can cause certain data bias. The relatively small number of questionnaires applied in every location could be considered one of the main limitations of this study. The limited number of ecotourism destinations could also be considered a research limit taking into account that such destinations have unique attractions and tourism offers. Another limitation is the application of research before the currently difficult situation regarding the COVID-19 pandemic, which certainly determined significant changes in the visitors' motivations when visiting ecotourism destinations.

Future research should replicate this study in order to find changes in the visitors' profile and behaviours. In this respect, AER aims to repeat the study every two years, with the help of its local partners, in order to measure the tendencies but also the efficiency of the marketing and management activities put into practice. The study is intended to be expanded to other destinations, as well as other time periods, in order to highlight the changes in the visitors' behaviour. Further research regarding visitors' responsibility in ecotourism destinations could also be useful for finding solutions to achieve sustainable development of these destinations. Such an approach is also proposed in the literature. Jeong [53] mentions that: "responsible behaviour occurs when tourists understand the impact of their behaviour on the environment and local people, and abide by the sociocultural and environmental norms of the site". For the sustainable destination management, it is important to be able to differentiate between the categories of tourists interested in protecting destination and the ones with a harmful behaviour. This information may help DMOs to make the best decisions for a sustainable development of the ecotourism destination. The outcomes of these decisions should satisfy both the economic interest of the local community and the goals to conserve the natural areas and cultural attractions.

Modern research tools, such as social network analysis, could be used in order to find possible relationships between the ecotourism destinations $[54,55]$. The results of such research could contribute to building "blockchains" [56] of information that can contribute to the sustainable development of the ecotourism destination by learning from the others' experience.

Author Contributions: Conceptualization, R.-G.A., A.N.C. and A.I.; data curation, V.P.-D. and A.B.; formal analysis, C.P.C. and R.-G.A.; investigation, V.P.-D., A.B. and T.S.; methodology, C.P.C., V.P.-D., A.N.C. and A.I.; validation, C.P.C., R.-G.A., A.N.C. and A.I.; visualization, C.P.C., T.S., A.N.C. and A.I.; writing—original draft, T.S. and A.I.; writing—review and editing, C.P.C., V.P.-D., A.B., R.-G.A., T.S. and A.N.C. All authors have read and agreed to the published version of the manuscript.

Funding: The APC was funded by Transylvania University of Brașov.

Institutional Review Board Statement: Not applicable.

Informed Consent Statement: Not applicable.

Data Availability Statement: Data sharing is not applicable to this article.

Acknowledgments: The authors would like to thank Association of Ecotourism in Romania (AER) for conducting this survey. 
Conflicts of Interest: The authors declare no conflict of interest.

\section{References}

1. Kotler, P.; Bowen, J.; Makens, J. Marketing for Hospitality and Tourism, 5th ed.; Pearson Prentice Hall: Upper Saddle River, NJ, USA, 2010.

2. Klimek, K. Destination management organizations and their shift to sustainable tourism development. Eur. J. Tour. Hosp. Recreat. 2013, 4, 27-47.

3. Wearing, S.L. National Parks, Tourism and Marketing. Australas. Parks Leis. J. 2008, 11, 29-33.

4. Perera, P.; Vlosky, R.P.; Wahala, S.B. Motivational and Behavioral Profiling of Visitors to Forest-based Recreational Destinations in Sri Lanka. Asia Pac. J. Tour. Res. 2012, 17, 451-467. [CrossRef]

5. Matthew, N.K.; Ahmad, S.; Sridar, R.; Syamsul Herman, M.A.; Kunjuraman, V. Profiling the segments of visitors in ad-venture tourism: Comparison between visitors by recreational sites. Int. J. Bus. Soc. 2019, 20, 1079-1095.

6. Stange, J.; Brown, D.; Hilbruner, R.; Hawkins, D.E. Tourism Destination Management-Achieving Sustainable and Competitive Results; USAID: Washington, WA, USA, 2011.

7. Weaver, D.B.; Lawton, L.J. Overnight Ecotourist Market Segmentation in the Gold Coast Hinterland of Australia. J. Travel Res. 2002, 40, 270-280. [CrossRef]

8. Deng, J.; Li, J. Self-identification of ecotourists. J. Sustain. Tour. 2014, 23, 255-279. [CrossRef]

9. Diaz-Christiansen, S.; López-Guzmán, T.; Gálvez, J.C.P.; Fernández, G.A.M. Wetland tourism in natural protected areas: Santay Island (Ecuador). Tour. Manag. Perspect. 2016, 20, 47-54. [CrossRef]

10. Kruger, M.; Van Der Merwe, P.; Saayman, M.; Slabbert, E. Understanding accommodation preferences of visitors to the Kruger National Park. Tour. Hosp. Res. 2017, 19, 170-185. [CrossRef]

11. Cui, X.; Lee, G.; Lee, S.J.; Kim, T.T. Structural Relationships among Antecedents to Perceived Value of Ecotourism for Sichuan Giant Pandas in China. Sustainability 2019, 11, 210. [CrossRef]

12. Agius, K.; Theuma, N.; Deidun, A.; Camilleri, L. Small islands as ecotourism destinations: A central Mediterranean perspective Isl. Stud. J. 2019, 14, 115-136. [CrossRef]

13. Hvenegaard, G.T. Using Tourist Typologies for Ecotourism Research. J. Ecotourism 2002, 1, 7-18. [CrossRef]

14. Bădulescu, A.; Bâc, D. Profile of ecotourists in the Apuseni Mountains natural park. Geoj. Tour. Geosites 2009, 3, 7-16.

15. Dragan, A.A.; Toader, V.; Petrescu, D.C. Development potential of ecotourism in Romania and Europe: Links between a macroeconomic perspective and consumer profile. In Trends in Hospitality, Proceedings of the International Conference Entrepreneurship in the Hospitality Industry, Cluj-Napoca, Romania, 9-11 October 2014, 3rd ed.; Universitatea Babeş-Bolyai: Cluj-Napoca, Romania, 2014; pp. 135-145.

16. Candrea, A.N.; Herțanu, A. Developing ecotourism destinations in Romania. A case study approach. Transilv. Bull. Econ. 2015, 8, 163-174.

17. Nistoreanu, P.; Dorobanțu, M.R.; Tuclea, C.E. The trilateral relationship ecotourism—sustainable tourism—slow travel among nature in the line with authentic tourism lovers. J. Tour. 2011, 11, 34-37.

18. Global Ecotourism Network. What is (not) Ecotourism? Available online: https:/ /www.globalecotourismnetwork.org/what-itis-not-ecotourism (accessed on 22 February 2021).

19. Mendes, S.; Martins, J.; Mouga, T. Ecotourism based on the observation of sea turtles-A sustainable solution for the touristic promotion of são tomé and príncipe. Cogent Soc. Sci. 2019, 5. [CrossRef]

20. Juvan, E.; Dolnicar, S. Measuring environmentally sustainable tourist behaviour. Ann. Tour. Res. 2016, 59, 30-44. [CrossRef]

21. Shi, F.; Weaver, D.; Zhao, Y.; Huang, M.-F.; Tang, C.; Liu, Y. Toward an ecological civilization: Mass comprehensive ecotourism indications among domestic visitors to a Chinese wetland protected area. Tour. Manag. 2019, 70, 59-68. [CrossRef]

22. Hornoiu, R.I.; Pădurean, M.A.; Nica, A.-M.; Maha, L.-G. Tourism Consumption Behavior in Natural Protected Areas. Amfiteatru Econ. 2014, 16, 1178-1190.

23. Carvache-Franco, M.; Segarra-Oña, M.; Carrascosa-López, C. Segmentation and motivations in eco-tourism: The case of a coastal national park. Ocean Coast. Manag. 2019, 178, 104812. [CrossRef]

24. Dudley, N. Guidelines for Applying Protected Area Management Categories; IUCN: Gland, Switzerland, 2008.

25. Eagles, P.P.J.; Bowman, M.E.; Tao, T.C.-H. Guidelines for Tourism in Parks and Protected Areas of East Asia; IUCN: Gland, Switzerland; Cambridge, UK, 2001.

26. Lindberg, K. Policies for Maximizing Nature Tourism's Ecological and Economic Benefits; International Conservation Financing Project Working Paper; World Resources Institute: Washington, DC, USA, 1991; pp. 1-37.

27. Mulyadi, A. Modeling of tourists, local population, natural and cultural resources toward ecotourism product (case study in Seagrass Trikora Conservation Area). Soc. Bus. Rev. 2019, 15, 1-20. [CrossRef]

28. Nicula, V.; Spânu, S. Ways of Promoting Cultural Ecotourism for Local Communities in Sibiu Area. Procedia Econ. Financ. 2014, 16, 474-479. [CrossRef]

29. Blanco-Cerradelo, L.; Gueimonde-Canto, A.; Fraiz-Brea, J.A.; Diéguez-Castrillón, M.I. Dimensions of destination competitiveness: Analyses of protected areas in Spain. J. Clean. Prod. 2018, 177, 782-794. [CrossRef]

30. Deng, J.; Li, J. Segmentation of Nature-Based Tourists in a Rural Area (2008-2009): A Single-Item Approach. Sustainability 2019, 11, 2052. [CrossRef] 
31. Cleaver, M.; Muller, T.E. The Socially Aware Baby Boomer: Gaining a Lifestyle-Based Understanding of the New Wave of Ecotourists. J. Sustain. Tour. 2002, 10, 173-190. [CrossRef]

32. Gu, X.P.; Lewis, B.J.; Niu, L.J.; Yu, D.P.; Zhou, L.; Zhou, W.M.; Gong, Z.; Tai, Z.; Dai, L.M. Segmentation by domestic visitor motivation: Changbai Mountain Biosphere Reserve, China. J. Mt. Sci. 2018, 15, 1711-1727. [CrossRef]

33. Sheena, B.; Mariapan, M.; Aziz, A. Characteristics of Malaysian ecotourist segments in Kinabalu Park, Sabah. Tour. Geogr. 2014, 17, 1-18. [CrossRef]

34. Adalilar, S.N.; Alkibay, S.; Eser, Z. Ecovillages as a Destination and a Study of Consumer Approaches to Ecovillages. Procedia Econ. Financ. 2015, 23, 539-546. [CrossRef]

35. Valle, P.O.D.; Pintassilgo, P.; Matias, A.; André, F. Tourist attitudes towards an accommodation tax earmarked for environmental protection: A survey in the Algarve. Tour. Manag. 2012, 33, 1408-1416. [CrossRef]

36. Kim, A.K.; Weiler, B. Visitors' attitudes towards responsible fossil collecting behaviour: An environmental attitude-based segmentation approach. Tour. Manag. 2013, 36, 602-612. [CrossRef]

37. Derek, M.; Woźniak, E.; Kulczyk, S. Clustering nature-based tourists by activity. Social, economic and spatial dimensions. Tour. Manag. 2019, 75, 509-521. [CrossRef]

38. Juravle, A.I.; Sasu, C.; Terec, V.L. The destination image of Bucovina among Romanian tourists. Cross Cult. Manag. J. 2016, 18, 139-150.

39. Saayman, M.; Slabbert, E. A profile of tourists visiting the Kruger National Park. Koedoe 2004, 47, 1-8. [CrossRef]

40. Nheta, D.S.; Madzunye, T.; Tshipala, N. Profile of Ecotourists within the Capricorn District Municipality, South Africa. Afr. J. Hosp. Tour. Leis. 2017, 6, 1-20.

41. Ogunjinmi, A.A. Analysis of Ecotourists' Profiles, Trip Characteristics, and Motivations in Nigeria National Parks. Geography 2015, 18, 25-48.

42. Amuquandoh, F.E. Tourists' motivations for visiting Kakum National Park, Ghana. Ghana J. Geogr. 2017, 9, 152-168.

43. Wight, P.A. Ecotourists: Not a Homogeneous Market Segment. In The Encyclopaedia of Ecotourism; Weaver, D.B., Ed.; CAB Intenational: Wallingford, UK, 2001; pp. 37-62. [CrossRef]

44. Fodness, D. Measuring tourist motivation. Ann. Tour. Res. 1994, 21, 555-581. [CrossRef]

45. National Tourism Authority in Romania. Criteria for the Designation of Ecotourism Destinations in Romania. Available online: http:/ /turism.gov.ro/web/wp-content/uploads/2021/02/Criterii-pentru-desemnarea-Destina\%C8\%9Biilor-Ecoturistice. pdf (accessed on 18 April 2020).

46. Discover Eco-Romania, About Ecotourism. Available online: https://www.eco-romania.ro/en/about-ecotourism/ (accessed on 18 April 2020).

47. Buhalis, D. Marketing the competitive destination of the future. Tour. Manag. 2000, 21, 97-116. [CrossRef]

48. Pike, S. Destination Marketing Organisations; Elsevier: Oxford, UK, 2004.

49. European Ecotourism Labelling Standard (EETLS). Available online: https://destinet.eu/resources/certificates/europeanecotourism-labelling-standard-eetls (accessed on 30 January 2021).

50. Eco-Destinet Network Is a Project Based Network of International Partners. Available online: http://www.ecotourism-network. eu/en-ecotourism-standard/en-the-euro-eco-label-stand (accessed on 30 January 2021).

51. Mehmetoglu, M. Typologising nature-based tourists by activity-Theoretical and practical implications. Tour. Manag. 2007, 28, 651-660. [CrossRef]

52. National Institute of Statistics. Tempo Online Statistics. 2018. Available online: http:/ /statistici.insse.ro:8077/tempo-online/\#/ pages/tables/insse-table (accessed on 13 April 2020).

53. Jeong, Y.; Zielinski, S.; Chang, J.-S.; Kim, S.-I. Comparing Motivation-Based and Motivation-Attitude-Based Segmentation of Tourists Visiting Sensitive Destinations. Sustainability 2018, 10, 3615. [CrossRef]

54. Valeri, M.; Baggio, R. Social network analysis: Organizational implications in tourism management. Int. J. Organ. Anal. 2020. [CrossRef]

55. Valeri, M.; Baggio, R. Italian tourism intermediaries: A social network analysis exploration. Curr. Issues Tour. 2020, 1-14. [CrossRef]

56. Valeri, M.; Baggio, R. A critical reflection on the adoption of blockchain in tourism. Inf. Technol. Tour. 2020, 1-12. [CrossRef] 